University of Massachusetts Amherst

ScholarWorks@UMass Amherst

Travel and Tourism Research Association: Advancing Tourism Research Globally

\title{
Using Travel Activities to Segment the Market for Travel: The Case of First-Time Visitors
}

Sean M. Hennessey PhD

Tourism Research Centre, School of Business Administration, University of Prince Edward Island

Dongkoo Yun PhD

Tourism Research Centre, School of Business Administration, University of Prince Edward Island

Roberta MacDonald PhD

Tourism Research Centre, School of Business Administration, University of Prince Edward Island

Follow this and additional works at: https://scholarworks.umass.edu/ttra

Hennessey, Sean M. PhD; Yun, Dongkoo PhD; and MacDonald, Roberta PhD, "Using Travel Activities to Segment the Market for Travel: The Case of First-Time Visitors" (2016). Travel and Tourism Research Association: Advancing Tourism Research Globally. 46.

https://scholarworks.umass.edu/ttra/2009/Presented_Papers/46

This is brought to you for free and open access by ScholarWorks@UMass Amherst. It has been accepted for inclusion in Travel and Tourism Research Association: Advancing Tourism Research Globally by an authorized administrator of ScholarWorks@UMass Amherst. For more information, please contact scholarworks@library.umass.edu. 


\title{
Using Travel Activities to Segment the Market for Travel: The Case of First-Time Visitors
}

\author{
Sean M. Hennessey, Ph.D. \\ Dongkoo Yun, Ph.D. \\ Roberta MacDonald, Ph.D. \\ Tourism Research Centre \\ School of Business Administration \\ University of Prince Edward Island \\ Charlottetown, Prince Edward Island, CANADA
}

\begin{abstract}
The main purpose of the study is to examine the relevance and significance of market segmentation based on the activities visitors engage in while at a destination. In doing so, the paper attempts to segment first-time pleasure travellers and profile the market by tiprelated characteristics. This paper is based on a subset of 1,104 first-time visitors to Prince Edward Island (PEI) in main season (July and August 2007). This study found that three distinct segments of first-time visitors exist: "culture-seeking," "active," and "other interest" tourists. In addition, the study identifies that cultural themes are an important factor for a significant portion of tourists visiting PEI and demonstrates that these culture-seekers are valuable in terms of their economic contribution to the destination and cultural/social interaction with communities.
\end{abstract}

\section{INTRODUCTION}

The activities travellers participate in while visiting a destination or activity preferences have been used to understand tourists' behaviour (Boorstin, 1971; Burns, 1999, Cohen, 1972; Kim \& Jogaratnam, 2003; Littrell, Paige \& Song, 2004; Rao, Thomas \& Javalgi, 1992). A number of previous studies illustrate that the activities visitors engage in while at destinations are an important way to differentiate between segments of the visitor population. This implies that groups of travellers who react in homogeneous way, be it in their motivations, behaviours, actions, reactions to marketing activities, or the benefits they seek from consuming products and services can be grouped (Sollner \& Rese, 2001). This enables products and services to be developed that can more effectively satisfy the differing needs of each segment. Travel market segmentation based on activities can offer insightful implications for tourism marketing.

While this approach to market segmentation has been subject to some criticism (McKercher \& Chan, 2005), the literature makes it clear that a variable that plays an important role in travel market segmentation studies is activity. From a broader view, the different types of preferred activities participated in can be considered subgroups of the total travel market (Choi \& Tsang, 1999; Lang, O’Leary, \& Morrison, 1993; Littrell, Paige, \& Song, 2004; Morrison, 1989; Morrison \& O’Leary, 1994; Moscardo, Pearce, \& Morrison, 2001). The choice of attractions or activities at destinations by travellers is determined by differences in the characteristics of the destinations visited, the travel elements that can be purchased prior to departure, as well as the characteristics of travellers to those destinations (Hyde, 2004). However, travel activities in and of 
themselves have been known as useful indices to understand tourists' behaviour (McIntosh \& Goeldner, 1990) and to identify their experiences at the destination (Ryan, 2002).

The main purpose of the study is to examine the relevance and significance of market segmentation based on the activities visitors engage in while at a destination. In doing so, the paper attempts to segment first-time pleasure travellers and profile the market by tiprelated characteristics.

\section{METHODOLOGY}

Data. This paper is based on the data collected using the Prince Edward Island Travel Survey of Visitors (hereafter the exit survey). The exit survey collected data using mailback surveys for pleasure visitors who spent at least one night in PEI during the 12month period the period July 1, 2007 to June 30, 2008. During this period approximately 367,000 travel parties exited PEI at one of the three points where it is possible to arrive on or depart from Prince: the Confederation Bridge, Northumberland Ferry, or the Charlottetown Airport (Tourism Research Centre, 2008). Over the year, a total of 4,539 surveys were completed, exceeding the original goal of 4,150. This paper is based on a subset of first-time visitors to PEI in main season (July and August 2007). A total of 1,104 exit surveys were completed by first-time visitors in main season. That is the subsample that is used for this paper.

Sample Characteristics. Table 1 provides the characteristics of the sample of firsttime visitors to PEI. Of the total surveys used, 584 were Canadian respondents $(52.9 \%)$, 364 were U.S. respondents $(33.0 \%)$ and 156 were other international respondents (14.1\%). Among respondents, about $62 \%$ were female, $84 \%$ were married, $56 \%$ worked full time, and $28 \%$ were retired. Respondents varied widely in age, education level, and annual household income.

Variables. One of the questions on the exit survey asks respondents to indicate which activities they participated in while visiting PEI. A total of 16 activities were provided; this paper is based on a subset of nine items: visiting historical and cultural attractions, visiting Canada's birthplace attractions, visiting Anne of Green Gables attractions, visiting a national or provincial park, attending a live theatre (performance), going to a beach, shopping for local craft/souvenir/antique, going to a lobster dinner (meal), participating in other sports and/or outdoor activities. These activities were used to cluster first-time travellers. To identify the characteristics of first-time travellers, demographic and trip-related variables were also used.

Data Analysis. The data analysis in this study proceeded in three stages. First, all respondents were grouped by using a $K$-means clustering procedure whereby a set of points is partitioned into $k$ groups (Pollard, 1981). This clustering method was employed to find disjoint clusters (Aldenderfer \& Blashfield, 1984; SAS Institute, Inc., 1990) with the means of each activity item serving as an input. In the second stage of the study, an analysis of variance (ANOVA), a multivariate analysis of variance (MANOVA), and a discriminant analysis were performed to determine whether the variables in each cluster group differed. Finally, Chi-Square analyses and ANOVAs were run to compare the differences between clusters, identify socio-demographic and trip-related characteristics of the clusters, and profile the clusters. 
Table 1. Socio-Demographic Profile of the Sample (Total $N=1,104)$.

\begin{tabular}{|c|c|c|}
\hline & $\mathrm{N}$ & Percentage \\
\hline \multicolumn{3}{|l|}{ Origin of First-time Visitors } \\
\hline Maritime (Nova Scotia and New Brunswick) & 41 & 3.7 \\
\hline Quebec & 168 & 15.2 \\
\hline Ontario & 248 & 22.5 \\
\hline Rest of Canada & 127 & 11.5 \\
\hline New England & 95 & 8.6 \\
\hline Rest of US & 269 & 24.4 \\
\hline International & 156 & 14.1 \\
\hline \multicolumn{3}{|l|}{ Gender } \\
\hline Male & 412 & 37.9 \\
\hline Female & 675 & 62.1 \\
\hline \multicolumn{3}{|l|}{ Age } \\
\hline 18 to 24 & 41 & 3.7 \\
\hline 25 to 34 & 162 & 14.8 \\
\hline 35 to 44 & 256 & 23.4 \\
\hline 45 to 54 & 219 & 20.0 \\
\hline 55 to 64 & 264 & 24.1 \\
\hline 65 and over & 152 & 13.9 \\
\hline \multicolumn{3}{|l|}{ Marital Status } \\
\hline Married or Living Common-law & 901 & 83.6 \\
\hline Single & 177 & 16.4 \\
\hline \multicolumn{3}{|l|}{ Education Level } \\
\hline Graduated high school or less & 95 & 8.9 \\
\hline Some post-secondary & 101 & 9.4 \\
\hline Graduated community or technical college & 250 & 23.3 \\
\hline Graduated university (undergraduate) & 371 & 34.5 \\
\hline Post graduate degree/Professional designation & 257 & 23.9 \\
\hline \multicolumn{3}{|l|}{ Employment Status } \\
\hline Working full time & 607 & 55.5 \\
\hline Working part time or seasonally & 75 & 6.9 \\
\hline Unemployed/ Retraining or upgrading & 8 & 0.8 \\
\hline Retired & 310 & 28.3 \\
\hline Homemaker & 52 & 4.8 \\
\hline Student & 30 & 2.7 \\
\hline Other & 12 & 1.1 \\
\hline \multicolumn{3}{|l|}{ Annual Household Income } \\
\hline Under $\$ 40,000$ & 78 & 8.3 \\
\hline$\$ 40,000$ to $\$ 59,999$ & 110 & 11.7 \\
\hline$\$ 60,000$ to $\$ 79,999$ & 143 & 15.2 \\
\hline$\$ 80,000$ to $\$ 99,999$ & 141 & 15.0 \\
\hline$\$ 100,000$ to $\$ 124,999$ & 159 & 16.9 \\
\hline$\$ 125,000$ to $\$ 149,999$ & 107 & 11.4 \\
\hline$\$ 150,000$ to $\$ 174,999$ & 85 & 9.1 \\
\hline$\$ 175,000$ to $\$ 199,999$ & 50 & 5.3 \\
\hline$\$ 200,000$ or more & 66 & 7.0 \\
\hline
\end{tabular}

Note: Differences in frequency between total number of samples used and respondents in each category are due to missing values. 


\section{RESULTS}

Cluster Analysis. Table 2 summarizes the statistics related to the clustering, ANOVA, MANOVA, and discriminant analyses. The ANOVA and MANOVA statistics illustrate that the clusters have very different levels of participation for the selected activity items, supporting the labels used to describe the clusters. Discriminant analysis was performed to examine which activity items highly contributed to the clusters and what percentage of hit ratio (or error count estimates for cluster) exists in the identified clusters. The results indicate that the model correctly classified $96.2 \%$ of the survey respondents into cluster groups. In terms of $R$-square of the nine activity items, "visiting historical and cultural attractions" was the most significant contributor to the clustering segments, closely followed by "visiting a national or provincial park." The next two activities (attending a live theatre and shopping for local craft/souvenir/ antique) were similar in terms of their contribution to the clustering model. The remaining five activities were significant but more minor contributors. Overall, statistics related to the clustering indicate that the clustering model was an excellent fit for the data.

Table 2. Summary of Clustering, ANOVAs, MANOVA and Discriminant Analysis.

\begin{tabular}{|c|c|c|c|c|c|c|}
\hline & Cluster 1 & Cluster 2 & Cluster 3 & Total & $F$-value & $R$-square \\
\hline \multicolumn{7}{|l|}{ Panel A: Clustering Statistics } \\
\hline Number of observations in cluster & 289 & 407 & 408 & 1,104 & & \\
\hline Percent of observations in cluster & $26.2 \%$ & $36.9 \%$ & $37.0 \%$ & $100 \%$ & & \\
\hline RMS Std. Deviation & 42.4 & 40.1 & 39.3 & & & \\
\hline Maximum distance from the seed to observation & 179.8 & 177.4 & 183.9 & & & \\
\hline Nearest cluster & 2 & 1 & 1 & & & \\
\hline Distance between cluster centroids & 108.7 & 108.7 & 130.1 & & & \\
\hline \multicolumn{7}{|l|}{ Panel B: ANOVA Statistics } \\
\hline Visiting historical and cultural attractions & 89.6 a & $79.4 \mathrm{~b}$ & $12.5 \mathrm{c}$ & 57.3 & $525.43 * * *$ & .4884 \\
\hline Visiting Canada's birthplace attractions & $46.0 \mathrm{a}$ & $24.6 \mathrm{~b}$ & $4.7 \mathrm{c}$ & 22.8 & $97.03 * * *$ & .1498 \\
\hline Visiting Anne of Green Gables attractions & $90.0 \mathrm{a}$ & $50.9 \mathrm{~b}$ & $35.0 \mathrm{c}$ & 55.3 & $130.37 * * *$ & .1915 \\
\hline Visiting a national or provincial park & $41.5 \mathrm{~b}$ & $93.6 \mathrm{a}$ & $15.0 \mathrm{c}$ & 50.9 & $487.04 * * *$ & .4694 \\
\hline Attending a live theatre (performance) & $75.4 \mathrm{a}$ & $8.8 \mathrm{c}$ & $36.0 \mathrm{~b}$ & 36.3 & $228.66 * * *$ & .2935 \\
\hline Going to a beach & $45.0 \mathrm{~b}$ & $87.0 \mathrm{a}$ & $52.2 \mathrm{~b}$ & 63.1 & $94.17 * * *$ & .1461 \\
\hline Shopping for local craft/souvenir/antique & $64.7 \mathrm{~b}$ & $77.1 \mathrm{a}$ & $19.6 \mathrm{c}$ & 52.6 & $199.36 * * *$ & .2659 \\
\hline Going to a lobster dinner (meal) & $69.2 \mathrm{a}$ & $47.7 \mathrm{~b}$ & $25.5 \mathrm{c}$ & 45.1 & $74.93 * * *$ & .1198 \\
\hline Participating in other sports and/or outdoor activities & $6.9 \mathrm{~b}$ & $20.6 \mathrm{a}$ & $5.4 \mathrm{~b}$ & 11.4 & $28.68 * * *$ & .0495 \\
\hline Panel C: MANOVA Statistics & Value & d.f. & $F$-value & $p$-value & & \\
\hline Wilks' Lambda & 0.134 & 18 & 210.33 & $<.0001$ & & \\
\hline Pillai's Trace & 1.249 & 18 & 201.96 & $<.0001$ & & \\
\hline Hotelling-Lawley Trace & 3.609 & 18 & 218.96 & $<.0001$ & & \\
\hline Roy's Greatest Root & 2.437 & 9 & 296.24 & $<.0001$ & & \\
\hline \multicolumn{7}{|l|}{ Panel D: Discriminant Statistics } \\
\hline Error Count Estimates for Cluster & .0554 & .0147 & .0441 & .0381 & & \\
\hline Hit Ratio (\%) & $(94.5 \%)$ & $(98.5 \%)$ & $(95.6 \%)$ & $(96.2 \%)$ & & \\
\hline Posterior Probability Error Rate Estimates for Cluster & .1587 & .0836 & .0940 & .1121 & & \\
\hline
\end{tabular}


The mean scores for all nine activities are significantly different at better than the 0.001 level for the three clusters. This table clearly illustrates that the 1,104 first-time travellers to PEI could be neatly partitioned into three cluster groups based on the nine activity items. Of the total, $289(26.2 \%)$ reported high involvement in culture activities and are termed "culture-seeking tourists." A further 407 (36.9\%) were high participants in natureand outdoor-based activities and are termed "active tourists." Finally, 408 (37.0\%) of the respondents had very low participation rates in almost all activities (with the exception of going to a beach and attending a live theatre production) and are termed "other interest tourists."

Visitor Origin by Cluster. Table 3 indicates that active visitors are primarily from Ontario and the rest of Canada, while other interest visitors are more likely to be from the two other Maritime Provinces, from Quebec, and from International origins. This later result is surprising, as it may have been expected that those travelling long distances would engage in more activities while at a destination. This is not the case for first-time visitors to PEI. Consistent with Table 2, culture seekers are in the minority for all origin markets, though culture is a stronger motivation for those for the rest of Canada and the US outside New England.

Table 3. Origin of First-time Visitors by Cluster.

\begin{tabular}{|c|c|c|c|c|c|}
\hline & & $\begin{array}{c}\text { Cluster 1: } \\
\text { Culture-seeking } \\
\text { Tourists }\end{array}$ & $\begin{array}{c}\text { Cluster 2: } \\
\text { Active } \\
\text { Tourists }\end{array}$ & $\begin{array}{c}\text { Cluster 3: } \\
\text { Other Interest } \\
\text { Tourists }\end{array}$ & Total \\
\hline \multirow[t]{3}{*}{ Maritime } & $\mathrm{N}$ & 7 & 10 & 24 & 41 \\
\hline & $\%$ (row) & $17.1 \%$ & $24.4 \%$ & $58.5 \%$ & $100.0 \%$ \\
\hline & $\%$ (column) & $2.4 \%$ & $2.5 \%$ & $5.9 \%$ & $3.7 \%$ \\
\hline \multirow[t]{3}{*}{ Quebec } & $\mathrm{N}$ & 29 & 63 & 76 & 168 \\
\hline & $\%$ (row) & $17.3 \%$ & $37.5 \%$ & $45.2 \%$ & $100.0 \%$ \\
\hline & $\%($ column $)$ & $10.0 \%$ & $15.5 \%$ & $18.6 \%$ & $15.2 \%$ \\
\hline \multirow[t]{3}{*}{ Ontario } & $\mathrm{N}$ & 56 & 119 & 73 & 248 \\
\hline & $\%$ (row) & $22.6 \%$ & $48.0 \%$ & $29.4 \%$ & $100.0 \%$ \\
\hline & $\%$ (column) & $19.4 \%$ & $29.2 \%$ & $17.9 \%$ & $22.5 \%$ \\
\hline \multirow[t]{3}{*}{ Rest of Canada } & $\mathrm{N}$ & 45 & 50 & 32 & 127 \\
\hline & $\%$ (row) & $35.4 \%$ & $39.4 \%$ & $25.2 \%$ & $100.0 \%$ \\
\hline & $\%$ (column) & $15.6 \%$ & $12.3 \%$ & $7.8 \%$ & $11.5 \%$ \\
\hline \multirow[t]{3}{*}{ New England } & $\mathrm{N}$ & 26 & 34 & 35 & 95 \\
\hline & $\%$ (row) & $27.4 \%$ & $35.8 \%$ & $36.8 \%$ & $100.0 \%$ \\
\hline & $\%$ (column) & $9.0 \%$ & $8.4 \%$ & $8.6 \%$ & $8.6 \%$ \\
\hline \multirow[t]{3}{*}{ Rest of US } & $\mathrm{N}$ & 80 & 87 & 102 & 269 \\
\hline & $\%$ (row) & $29.7 \%$ & $32.3 \%$ & $37.9 \%$ & $100.0 \%$ \\
\hline & $\%$ (column) & $27.7 \%$ & $21.4 \%$ & $25.0 \%$ & $24.4 \%$ \\
\hline \multirow[t]{3}{*}{ International } & $\mathrm{N}$ & 46 & 44 & 66 & 156 \\
\hline & $\%$ (row) & $29.5 \%$ & $28.2 \%$ & $42.3 \%$ & $100.0 \%$ \\
\hline & $\%$ (column) & $15.9 \%$ & $10.8 \%$ & $16.2 \%$ & $14.1 \%$ \\
\hline \multirow[t]{3}{*}{ Total } & $\mathrm{N}$ & 289 & 407 & 408 & 1,104 \\
\hline & $\%$ (row) & $26.2 \%$ & $36.9 \%$ & $37.0 \%$ & $100.0 \%$ \\
\hline & $\%$ (column) & $100.0 \%$ & $100.0 \%$ & $100.0 \%$ & $100.0 \%$ \\
\hline
\end{tabular}

Chi-Square Statistics: $\chi^{2}$ value $=46.88$; d.f. $=12, p=.000$ 
Trip-related Characteristics by Cluster. Table 4 indicates that first-time visitors attracted by the natural beauty and pastoral setting of PEI ( $42.2 \%$ of the overall sample) are more likely to be active visitors, while those attracted by beaches and the coast line are equally likely to be active or other interest visitors. The almost $15 \%$ of first-time visitors attracted by the "world of Anne of Green Gables" are much more likely to be culture-seekers. Fittingly, those attracted by other features are other interest visitors.

Table 4. Primary Features that Attracted First-Time Visitors by Cluster.

\begin{tabular}{|c|c|c|c|c|c|}
\hline & & $\begin{array}{c}\text { Cluster 1: } \\
\text { Culture-seeking } \\
\text { Tourists } \\
\end{array}$ & $\begin{array}{c}\text { Cluster 2: } \\
\text { Active } \\
\text { Tourists } \\
\end{array}$ & $\begin{array}{c}\text { Cluster 3: } \\
\text { Other Interest } \\
\text { Tourists } \\
\end{array}$ & Total \\
\hline Natural Beauty and & $\mathrm{N}$ & 117 & 177 & 137 & 431 \\
\hline \multirow[t]{2}{*}{ Pastoral Settings } & $\%$ (row) & $27.1 \%$ & $41.1 \%$ & $31.8 \%$ & $100.0 \%$ \\
\hline & $\%$ (column) & $44.5 \%$ & $44.7 \%$ & $37.7 \%$ & $42.2 \%$ \\
\hline \multirow[t]{3}{*}{$\begin{array}{l}\text { Beaches and Coast } \\
\text { Line }\end{array}$} & $\mathrm{N}$ & 33 & 97 & 96 & 226 \\
\hline & $\%$ (row) & $14.6 \%$ & $42.9 \%$ & $42.5 \%$ & $100.0 \%$ \\
\hline & $\%$ (column) & $12.5 \%$ & $24.5 \%$ & $26.4 \%$ & $22.1 \%$ \\
\hline World of Anne of & $\mathrm{N}$ & 64 & 40 & 48 & 152 \\
\hline \multirow[t]{2}{*}{ Green Gables } & $\%$ (row) & $42.1 \%$ & $26.3 \%$ & $31.6 \%$ & $100.0 \%$ \\
\hline & $\%$ (column) & $24.3 \%$ & $10.1 \%$ & $13.2 \%$ & $14.9 \%$ \\
\hline Canada Birthplace & $\mathrm{N}$ & 8 & 7 & 1 & 16 \\
\hline \multirow[t]{2}{*}{ Attractions } & $\%$ (row) & $50.0 \%$ & $43.8 \%$ & $6.3 \%$ & $100.0 \%$ \\
\hline & $\%$ (column) & $3.0 \%$ & $1.8 \%$ & $0.3 \%$ & $1.6 \%$ \\
\hline \multirow[t]{3}{*}{ Golf } & $\mathrm{N}$ & 3 & 7 & 6 & 16 \\
\hline & $\%$ (row) & $18.8 \%$ & $43.8 \%$ & $37.5 \%$ & $100.0 \%$ \\
\hline & $\%$ (column) & $1.1 \%$ & $1.8 \%$ & $1.7 \%$ & $1.6 \%$ \\
\hline \multirow[t]{3}{*}{ Culinary Experience } & $\mathrm{N}$ & 6 & 11 & 9 & 26 \\
\hline & $\%$ (row) & $23.1 \%$ & $42.3 \%$ & $34.6 \%$ & $100.0 \%$ \\
\hline & $\%$ (column) & $2.3 \%$ & $2.8 \%$ & $2.5 \%$ & $2.5 \%$ \\
\hline \multirow[t]{3}{*}{ Outdoor Activities } & $\mathrm{N}$ & 1 & 16 & 3 & 20 \\
\hline & $\%$ (row) & $5.0 \%$ & $80.0 \%$ & $15.0 \%$ & $100.0 \%$ \\
\hline & $\%$ (column) & $0.4 \%$ & $4.0 \%$ & $0.8 \%$ & $2.0 \%$ \\
\hline \multirow[t]{3}{*}{ Other Features } & $\mathrm{N}$ & 31 & 41 & 63 & 135 \\
\hline & $\%$ (row) & $23.0 \%$ & $30.4 \%$ & $46.7 \%$ & $100.0 \%$ \\
\hline & $\%$ (column) & $11.8 \%$ & $10.4 \%$ & $17.4 \%$ & $13.2 \%$ \\
\hline \multirow[t]{3}{*}{ Total } & $\mathrm{N}$ & 263 & 396 & 363 & 1,022 \\
\hline & $\%$ (row) & $25.7 \%$ & $38.7 \%$ & $35.5 \%$ & $100.0 \%$ \\
\hline & $\%$ (column) & $100.0 \%$ & $100.0 \%$ & $100.0 \%$ & $100.0 \%$ \\
\hline
\end{tabular}

Chi-Square Statistics: $\chi^{2}$ value $=70.44 ;$ d.f. $=14, p=.000$

Table 5 shows that of the first-time visitors whose primary destination was PEI; the majority is active visitors, while those with primary destinations other than PEI are mostly other interest visitors.

Table 6 reports that travel party size for culture-seekers (3.45 people) was significantly larger than for active (3.07) or other interest (2.88) visitors, as is number of nights spent on PEI (4.71 verses 4.51 verses 3.21). These differences explain why per person per night spending for culture-seeking and other interest visitors were similar. 
Table 5. Primary Destination of First-time Visitors by Cluster.

\begin{tabular}{llcccc}
\hline \hline & & $\begin{array}{c}\text { Cluster 1: } \\
\text { Culture-seeking } \\
\text { Tourists }\end{array}$ & $\begin{array}{c}\text { Cluster 2: } \\
\text { Active } \\
\text { Tourists }\end{array}$ & $\begin{array}{c}\text { Cluster 3: } \\
\text { Other Interest } \\
\text { Tourists }\end{array}$ & Total \\
\hline Prince Edward Island & $\mathrm{N}$ & 161 & 237 & 181 & 579 \\
& $\%$ (row) & $27.8 \%$ & $40.9 \%$ & $31.3 \%$ & $100.0 \%$ \\
& $\%$ (column) & $56.7 \%$ & $59.1 \%$ & $45.0 \%$ & $53.3 \%$ \\
\hline Other Destinations & $\mathrm{N}$ & 123 & 164 & 221 & 508 \\
& $\%$ (row) & $24.2 \%$ & $32.3 \%$ & $43.5 \%$ & $100.0 \%$ \\
& $\%$ (column) & $43.3 \%$ & $40.9 \%$ & $55.0 \%$ & $46.7 \%$ \\
\hline Total & $\mathrm{N}$ & 284 & 401 & 402 & 1,087 \\
& $\%$ (row) & $26.1 \%$ & $36.9 \%$ & $37.0 \%$ & $100.0 \%$ \\
& $\%$ (column) & $100.0 \%$ & $100.0 \%$ & $100.0 \%$ & $100.0 \%$ \\
\hline
\end{tabular}

Chi-Square Statistics: $\chi^{2}$ value $=17.79$; d.f. $=2, p=.000$

Table 6. Average Travel Party Size and Trip Duration by Cluster.

\begin{tabular}{lccccc}
\hline \hline & $\begin{array}{c}\text { Cluster 1: } \\
\text { Culture-seeking } \\
\text { Tourists }\end{array}$ & $\begin{array}{c}\text { Cluster 2: } \\
\text { Active } \\
\text { Tourists }\end{array}$ & $\begin{array}{c}\text { Cluster 3: } \\
\text { Other Interest } \\
\text { Tourists }\end{array}$ & Total & F-value \\
\hline Average Party Size & $3.45 \mathrm{a}$ & $3.07 \mathrm{ab}$ & $2.88 \mathrm{~b}$ & 3.10 & $2.94^{*}$ \\
\hline $\begin{array}{l}\text { Average Number of } \\
\text { Night stayed on PEI }\end{array}$ & $4.71 \mathrm{a}$ & $4.51 \mathrm{a}$ & $3.21 \mathrm{~b}$ & 4.08 & $22.19^{* * *}$ \\
\hline \hline
\end{tabular}

Notes: $\mathrm{a}, \mathrm{b}$, and $\mathrm{c}$ indicate result of the post-hoc test using Duncan's Multiple Range test; $* p<.05 ; * * * p<.001$

Table 7 presents spending data by travel segment. Clearly, culture-seekers are the highest spenders in total, per-party and per person per night. For this later category, it should be noted that while other interest visitors do not engage in a great deal of activities, they do spend a comparable amount on a per person per night basis as culture-seeking visitors. This is due to higher spending on accommodations and in restaurants.

In results that are unreported, it is interesting to note that marital status, household income, and travel party composition are not useful measures to segment this group of visitors into one of the three clusters. For all three variables, the Chi-squares statistics are insignificant.

\section{IMPLICATIONS AND CONCLUSIONS}

This paper presented a method to segment and profile the market using travel activities participated in for first time visitors to Prince Edward Island (PEI), a small province on the east coast of Canada that is a major tourist destination. The results indicated that there are three distinct segments of visitors: "culture-seeking," "active," and "other interest" tourists. The results for the other interest tourists seem to suggest that the millions that the public and private sectors are spending on branding and marketing PEI as "The Gentle Island" is working. These visitors seem to view PEI as a place to "lay back, relax, and get away from our hectic lifestyle." 
Table 11. Travel Expenditures of First-time Visitors by Cluster.

\begin{tabular}{llllll}
\hline \hline & $\begin{array}{c}\text { Cluster 1: } \\
\text { Culture- } \\
\text { seeking } \\
\text { Tourists }\end{array}$ & $\begin{array}{c}\text { Cluster 2: } \\
\text { Active } \\
\text { Tourists }\end{array}$ & $\begin{array}{c}\text { Cluster 3: } \\
\text { Other Interest } \\
\text { Tourists }\end{array}$ & Total & F-value \\
\hline $\begin{array}{l}\text { Total Average Spending } \\
\text { per Party per Visit }\end{array}$ & $\$ 1,345.96 \mathrm{a}$ & $\$ 1,099.06 \mathrm{~b}$ & $\$ 935.64 \mathrm{c}$ & $\$ 1,102.65$ & $14.79^{* * *}$ \\
\hline $\begin{array}{l}\text { Total Average Spending } \\
\text { per Party per Night }\end{array}$ & $\$ 321.35 \mathrm{a}$ & $\$ 277.80 \mathrm{~b}$ & $\$ 305.56 \mathrm{ab}$ & $\$ 298.97$ & $4.73^{* *}$ \\
\hline $\begin{array}{l}\text { Total Average Spending } \\
\text { per Person per Visit }\end{array}$ & $\$ 529.07 \mathrm{a}$ & $\$ 422.50 \mathrm{~b}$ & $\$ 382.00 \mathrm{~b}$ & $\$ 434.95$ & $11.51^{* * *}$ \\
\hline $\begin{array}{l}\text { Total Average Spending } \\
\text { per Person per Night }\end{array}$ & $\$ 128.06 \mathrm{a}$ & $\$ 107.47 \mathrm{~b}$ & $\$ 124.51 \mathrm{a}$ & $\$ 118.90$ & $7.58^{* *}$ \\
\hline Categories of Spending & & & & & \\
\hline Accommodation & $\$ 49.19 \mathrm{a}$ & $\$ 39.80 \mathrm{~b}$ & $\$ 53.13 \mathrm{a}$ & $\$ 47.03$ & $10.89^{* * *}$ \\
\hline Restaurants & $\$ 24.70 \mathrm{ab}$ & $\$ 23.08 \mathrm{~b}$ & $\$ 27.13 \mathrm{a}$ & $\$ 24.96$ & $4.04 *$ \\
\hline Food \& Beverage at Stores & $\$ 5.74 \mathrm{ab}$ & $\$ 6.62 \mathrm{a}$ & $\$ 4.80 \mathrm{~b}$ & $\$ 5.73$ & $4.05^{*}$ \\
\hline $\begin{array}{l}\text { Vehicle Operation \& Local } \\
\text { Transportation }\end{array}$ & $\$ 10.48$ & $\$ 11.00$ & $\$ 11.48$ & $\$ 11.04$ & 0.43 \\
\hline Car Rentals & $\$ 4.19 \mathrm{a}$ & $\$ 1.14 \mathrm{~b}$ & $\$ 2.59 \mathrm{~b}$ & $\$ 2.45$ & $7.81^{* * *}$ \\
\hline Shopping & $\$ 15.47$ & $\$ 15.39$ & $\$ 11.01$ & $\$ 13.82$ & 2.80 \\
\hline Recreation \& Entertainment & $\$ 14.20 \mathrm{a}$ & $\$ 7.46 \mathrm{~b}$ & $\$ 13.03 \mathrm{ab}$ & $\$ 11.20$ & $20.32^{* * * *}$ \\
\hline Other Expenditures & $\$ 4.08$ & $\$ 2.97 \mathrm{ab}$ & $\$ 1.35 \mathrm{~b}$ & $\$ 2.67$ & $3.67 *$ \\
\hline \hline
\end{tabular}

Notes: Total average expenditures and categories of spending in these results were based on all first-time travellers rather than those who only reported spending on that category; Categories of spending indicate average spending per person per night; $a$, b, and $\mathrm{c}$ indicate results of the post-hoc test for each variable using Duncan's Multiple Range test; $* p<.05 ; * * p<.01 ; * * * p<.001$

In addition, the study has identified that cultural themes are an important factor for a significant portion of tourists visiting PEI and demonstrated that these culture-seekers are valuable in terms of their economic contribution to the destination and cultural/social interaction with communities. This, in turn, will impact public policy and the investment made in a destination's tourism "product." Cultural tourism can result in the preservation of a destination's cultural heritage and values for future generations, resulting in positive attitudes toward tourism by both residents and visitors (McKercher, 2002). Based on the results, it is clear that tourism marketers and operators need to emphasize culturally unique elements of a destination and provide a variety of travel information sources to appeal and attract more distant (mid- and long-haul) markets and first-time visitors.

Culture-seeking tourists in this study also prefer to participate in other activities especially those related to nature, recreation, and entertainment. Therefore, cultural tourism should be presented in a manner that is accessible, enjoyable and easy to consume such as packaged offerings and special services. Successful products that cater to these needs may lead to increased tourism demand and the growing supply of cultural attractions. Cultural products that ignore this maxim will struggle to find a sustainable consumer base. 


\section{REFERENCES}

Aldenderfer, M. S., \& Blashfield, R. K. (1984). Cluster Analysis, Beverly Hills, CA: Sage Publications.

Boorstin, D. J. (1971). The Image: A Guide to Pseudo-Events in America. (3rd. ed.). New York: Atheneum.

Burns, P. M. (1999). An Introduction to Tourism and Anthropology. London: Routledge.

Choi, W. M., \& Tsang, C. K. L. (1999). Activity Based Segmentation on Pleasure Travel Market of Hong Kong Private Housing Residents. Journal of Travel \& Tourism Marketing, 8(2): 75-97.

Cohen, E. (1972). Toward a Sociology of International Tourism. Social Research, 39(1), 164-182.

Hyde, K. F. (2004). A Duality in Vacation Decision Making. In M. Geoffrey I. Crouch, Richard R. Perdue, Harry J. P. Timmermans, \& Muzaffer Uysal (Eds.), Consumer Psychology of Tourism, Hospitality and Leisure, Volume 3 (pp. 161-180). London: Academic Press, Inc.

Kim, K., \& Jogaratnam, G. (2003). Activity Preferences of Asian International and Domestic American University Students: An Alternate Basis for Segmentation. Journal of Vacation Marketing, 9(3), 260-270.

Kotler, P., \& Armstrong, G. (1991). Principles of Marketing (5th ed.). Englewood Cliffs, N.J.: Prentice-Hall International Inc.

Kotler, P., Bowen, J., \& Makens, J. (2003). Marketing for Hospitality and Tourism (3rd. ed.). New Jersey: Prentice Hall.

Kotler, P., Haider, J., \& Rein, I. (1993). Marketing Places: Attracting Investment, Industry and Tourism to Cities, States and Nations. New York: The Free Press.

Lang, C. T., O’Leary, J. T., \& Morrison, A. M. (1993). Activity Segmentation of Japanese Female Overseas Travellers. Journal of Travel \& Tourism Marketing, 2(4): 1-21.

Littrell, M. A., Paige, R. C., Song, K. (2004). Senior Travellers: Tourism Activities and Shopping Behaviours. Journal of Vacation Marketing, 10(4), 348-362.

McIntosh, R. W., \& Goeldner, C. R. (1990). Tourism: Principles, Practices, and Philosophies (Sixth ed.). New York: John Wiley \& Sons, Inc.

McKercher, B. (2002). Towards a Classification of Cultural Tourists. The International Journal of Tourism Research, 4(1): 29-38.

McKercher, B., \& Chan, A., (2005). How Special Is Special Interest Tourism? Journal of Travel Research, 44(1): 21-31.

Morrison, A. M., \& O'Leary J. T. (1994). Segmenting the Australian Domestic Travel Market by Holiday Activity Participation. The Journal of Tourism Studies, 5(1): 39-55.

Morrison, A.M. (1989). Hospitality and Travel Marketing, United States of America: Delmar.

Moscardo, G. M., Pearce, P. L., \& Morrison, A. M. (2001). Evaluating Different Bases for Market Segmentation: A Comparison of Geographic Origin versus Activity Participation for Generating Tourist Market Segments. Journal of Travel \& Tourism Marketing, 10(1): 29-49.

Pollard, D. (1981). Strong Consistency of K-means Clustering. The Annals of Statistics, 9(1): 135-140. 
Rao, S. R., Thomas, E. G., \& Javalgi, R. G. (1992), Activity Preferences and Tripplanning Behavior of the U. S. Outbound Pleasure Travel Market. Journal of Travel Research, 30(3), 3-12.

Ryan, C. (2002). The Tourist Experience. London: Continuum.

SAS Institute Inc. (1990). SAS/STAT User's Guide, Version 6 (Fourth edition), Volume 1, Cary, NC: SAS Institute Inc.

Sollner, A., \& Rese, M. (2001). Market Segmentation and the Structure of Competition: Application of the Strategic Group Concept for an Improved Market Segmentation on Industrial Markets. Journal of Business Research, 51(1): 25-36.

Tourism Research Centre (2008). Overall Results for the 2007-2008 Exit Survey: Results for the Year from July 1, 2007 to June 30, 2008. Charlottetown: University of Prince Edward Island.

\section{Contact information:}

Dr. Sean M. Hennessey, Director and Professor

Tourism Research Centre

School of Business Administration

University of Prince Edward Island

Charlottetown, Prince Edward Island, C1A 4P3

Canada

Tel: (902) 566-0523

Fax: (902) 628-4302

Email: hennessey@upei.ca 